\title{
Fenoxaprop Activity Influenced by Auxin-like Herbicide Application Timing
}

\author{
P.H. Dernoeden and M.A. Fidanza \\ Department of Agronomy, University of Maryland, College Park, MD 20742
}

Additional index words. Digitaria ischaemum, 2,4-D, mecoprop, dicamba

Abstract. Fenoxaprop is used on turfgrasses to control smooth crabgrass [Digitaria ischaemum (Schreb. ex Sweib.) Schreb. ex Muhl.] and other annual grass weeds. Our objective was to determine if a broadleaf weed herbicide (BWH $=2,4-D+$ mecoprop + dicamba) would affect fenoxaprop activity. The BWH was applied several days or weeks before and after fenoxaprop was applied. Smooth crabgrass control by fenoxaprop was reduced significantly when the BWH was applied $\leq 14$ days before fenoxaprop was applied. Extremely poor crabgrass control occurred when fenoxaprop was tank-mixed with the BWH. There was no reduction in crabgrass control when the BWH was applied 21 days before or $\geq 3$ days after fenoxaprop. Chemical names used: ethyl ester of $( \pm)-2-[4-[(6-$ chloro-2-benzoxazolyl)oxy]phenoxy]propanoic acid (fenoxaprop); 2,4-dichlorophenoxy acetic acid (2,4-D); (+)-2-(4-chloro-2-methylphenoxy)propanoic acid (mecoprop); 3,6dichloro-2-methoxybenzoic acid (dicamba).

Fenoxaprop is a postemergence graminicide used on turfgrasses to control crabgrass (Digitaria spp.) and other annual grass weeds. Broadleaf weeds are commonly controlled in turfgrasses by several auxin-like herbicides. The most widely used materials are 2,4-D, mecoprop, and dicamba, which are frequently sold together in prepackaged mixtures.

Broadleaf weeds and crabgrass often are found together in turfgrasses, and it may be advantageous to tank-mix a broadleaf herbicide with a graminicide to control a diverse number of weed species simultaneously. Previous research has shown that when fenoxaprop was tank-mixed with several commercial broadleaf herbicides, broadleaf weed control was normally good, but crabgrass control was only poor to fair (Dernoeden, 1986; Sawyer and Jagschitz, 1988; Watschke and Hamilton, 1986). Harrison (1987) described the reduced fenoxaprop activity controlling annual grass weeds when tank-mixed with a broadleaf herbicide as "antagonism." Our objective was to determine if a prepackaged mix of 2,4-D + mecoprop + dicamba would antagonize fenoxaprop if applied several days or weeks before or following the fenoxaprop application.

\section{Materials and Methods}

Studies were conducted in Silver Spring, Md., in 1992 and 1993 on mature stands of 'Kenblue' Kentucky bluegrass (Poa pratensis

Received for publication 14 Jan. 1994. Accepted for publication 27 July 1994. Maryland Agricultural Expt. Station Scientific Article no. A6540 and Contribution no. 8751. The cost of publishing this paper was defrayed in part by the payment of page charges. Under postal regulations, this paper therefore must be hereby marked advertisement solely to indicate this fact.
L.) and 'Flyer' creeping red fescue (Festuca rubra L. ssp. rubra). Both grasses were grown on Chillum silt loam (fine silty, mixed, mesic Typic Hapludult) with 18 to $27 \mathrm{mg}$ organic matter per gram of soil and soil $\mathrm{pH}$ ranging from 5.9 to 6.8 . Turf was mowed at 50 to 60 $\mathrm{mm}$ and was irrigated before each herbicide application and thereafter to prevent drought

Table 1. Smooth crabgrass control by fenoxaprop as influenced by a broadleaf weed herbicide (BWH) and its application timing in 1992.

\begin{tabular}{|c|c|c|c|}
\hline \multirow{3}{*}{$\begin{array}{l}\text { Time of BWH } \\
\text { application (days) }\end{array}$} & \multicolumn{3}{|c|}{$\begin{array}{c}\text { Area covered } \\
\text { by crabgrass }(\%)\end{array}$} \\
\hline & \multicolumn{3}{|c|}{ Date evaluated (July) } \\
\hline & 14 & 20 & 2 \\
\hline \multicolumn{4}{|l|}{ Before fenoxaprop (BF) } \\
\hline $10^{\mathrm{z}}$ & 7 & 9 & 3 \\
\hline 7 & 5 & 7 & 3 \\
\hline 5 & 2 & 6 & 3 \\
\hline 3 & 6 & 8 & 3. \\
\hline Fenoxaprop alone (Fa) & 1 & 2 & 1 \\
\hline \multicolumn{4}{|l|}{ After fenoxaprop (AF) } \\
\hline 3 & 2 & 2 & 15 \\
\hline 5 & $<1$ & 1 & 1 \\
\hline 7 & $<1$ & $<1$ & 10 \\
\hline 10 & $<1$ & $<1$ & \\
\hline Nontreated & 49 & 68 & \\
\hline & \multicolumn{3}{|c|}{ Level of significance } \\
\hline \multicolumn{4}{|l|}{ Contrasts } \\
\hline $10 \mathrm{BF}$ vs. Fa & $*$ & $* *$ & $*$ \\
\hline $7 \mathrm{BF}$ vs. Fa & $*$ & $*$ & $*$ \\
\hline $5 \mathrm{BF}$ vs. Fa & NS & $*$ & \\
\hline $3 \mathrm{BF}$ vs. Fa & $* *$ & $* *$ & \\
\hline 3 AF vs. Fa & NS & NS & $\mathrm{N}$ \\
\hline 5 AF vs. Fa & NS & NS & \\
\hline 7 AF vs. Fa & NS & NS & \\
\hline $10 \mathrm{AF}$ vs. Fa & NS & NS & \\
\hline Nontreated vs. Fa & $* * *$ & $* * *$ & \\
\hline
\end{tabular}

${ }^{\mathrm{z}} \mathrm{BWH}$ ( 2,4-D + mecoprop + dicamba) was applied at $1.96 \mathrm{~kg} \cdot \mathrm{ha}^{-1}$ on each date. Fenoxaprop 1EC was applied at $0.20 \mathrm{~kg} \cdot \mathrm{ha}^{-1}$ when smooth crabgrass was in the two-leaf to two-tiller stage on 22 June 1992. ss, ${ }^{*}, * *{ }^{* * *}$ Nonsignificant or significant at $P \leq 0.05$, 0.01 , or 0.001 , respectively. stress. The mean daily temperatures during the 14 days before applying fenoxaprop ranged from 21 to $24 \mathrm{C}$ and 24 to $29 \mathrm{C}$ in 1992 and 1993 , respectively. The mean daily temperature 14 days after applying fenoxaprop ranged from 23 to $27 \mathrm{C}$ in both years. Total precipitation during the 14 days before and after applying fenoxaprop was 146 and $119 \mathrm{~mm}$ in 1992 and 1993, respectively.

The timing of each herbicide application is shown in Tables 1 and 2. Fenoxaprop was applied at 0.20 and $0.28 \mathrm{~kg} \cdot \mathrm{ha}^{-1}$ in 1992 and 1993, respectively. The smooth crabgrass was at the two-leaf to eight-tiller stage when fenoxaprop was applied. The prepackaged mixture of broadleaf weed herbicide $(\mathrm{BWH})$ was applied at (in kg.ha-1) 1.20 2,4-D + 0.65 mecoprop +0.11 dicamba in both years. Herbicide applications were made with a $\mathrm{CO}_{2}{ }^{-}$ pressurized backpack sprayer (RND Sprayers, Opelousas, La.), equipped with an 8004 flat fan nozzle calibrated to deliver 467 liters.ha ${ }^{-1}$ at $262 \mathrm{kPa}$.

Herbicide-treated and nontreated plots were arranged in a randomized complete-block design with four replicates. Individual plots were $1.5 \times 1.5 \mathrm{~m}$. Percent smooth crabgrass coverage was evaluated visually on the dates noted in Tables 1 and 2 on a $0 \%$ to $100 \%$ linear scale, where $0 \%=$ no crabgrass present and $100 \%=$ entire plot area covered by crabgrass. Arcsintransformed percentage data were subjected to

Table 2. Smooth crabgrass control by fenoxaprop as influenced by a broadleaf weed herbicide (BWH) and its application timing in 1993.

\begin{tabular}{|c|c|c|c|}
\hline \multirow{3}{*}{$\begin{array}{l}\text { Time of BWH } \\
\text { application (days) }\end{array}$} & \multirow{2}{*}{\multicolumn{3}{|c|}{$\begin{array}{c}\text { Area covered } \\
\text { by crabgrass }(\%) \\
\text { Date evaluated }\end{array}$}} \\
\hline & & & \\
\hline & 26 July & 9 Aug & Aug \\
\hline \multicolumn{4}{|l|}{ Before fenoxaprop (BF) } \\
\hline 21 & 1 & 2 & 5 \\
\hline 14 & 2 & 3 & 8 \\
\hline 10 & 4 & 8 & 14 \\
\hline 7 & 7 & 19 & 27 \\
\hline Fenoxaprop alone (Fa) & 1 & 2 & 4 \\
\hline \multicolumn{4}{|l|}{ Tank-mixed } \\
\hline \multicolumn{4}{|l|}{ After fenoxaprop (AF) } \\
\hline 3 & $<1$ & 0 & $<1$ \\
\hline 5 & 1 & 0 & $<1$ \\
\hline 7 & $<1$ & $<1$ & $<1$ \\
\hline 10 & 1 & 0 & $<1$ \\
\hline \multirow[t]{2}{*}{ Nontreated } & 69 & 77 & 87 \\
\hline & \multicolumn{3}{|c|}{ Level of significance } \\
\hline \multicolumn{4}{|l|}{ Contrasts } \\
\hline $21 \mathrm{BF}$ vs. Fa & NS & NS & NS \\
\hline 14 BF vs. Fa & $*$ & $*$ & $*$ \\
\hline $10 \mathrm{BF}$ vs. Fa & $* * *$ & $* * *$ & $* * *$ \\
\hline $7 \mathrm{BF}$ vs. Fa & $* * *$ & $* * *$ & $* * *$ \\
\hline 3 AF vs. Fa & NS & NS & NS \\
\hline $5 \mathrm{AF}$ vs. Fa & NS & NS & NS \\
\hline 7 AF vs. Fa & NS & NS & NS \\
\hline 10 AF vs. Fa & NS & NS & NS \\
\hline \multicolumn{4}{|l|}{ Mixed with } \\
\hline fenoxaprop vs. Fa & $* * *$ & $* * *$ & $* * *$ \\
\hline Nontreated vs. Fa & $* * *$ & $* * *$ & $* * *$ \\
\hline
\end{tabular}

$\overline{{ }^{2} \mathrm{BWH}(2,4-\mathrm{D}+\text { mecoprop + dicamba) was applied }}$ at $1.96 \mathrm{~kg} \cdot \mathrm{ha}^{-1}$ on each date. Fenoxaprop 1EC was applied at $0.28 \mathrm{~kg} \cdot \mathrm{ha}^{-1}$ when smooth crabgrass was in the two-leaf to eight-tiller stage on 6 July 1993. ns, *, **, *** Nonsignificant or significant at $P \leq 0.05$, 0.01 , or 0.001 , respectively. 
analyses of variance, and predetermined, single degree-of-freedom contrasts were used to show the treatment effects (SAS Institute, 1985); however, actual means are shown.

\section{Results and Discussion}

1992. The final BWH treatment was applied on 2 July (i.e., 10 days after fenoxaprop), and plots were first rated for crabgrass coverage on 14 July (Table 1). Although crabgrass infestation was low in herbicide-treated plots, BWH applied 3, 7, or 10 days before fenoxaprop application resulted in reduced crabgrass control. Crabgrass coverage data collected 20 and 27 July 1992 reflect primarily regrowth of herbicide-injured smooth crabgrass as well as some crabgrass seed germination after the fenoxaprop application on 22 June. All BWH plots sprayed before fenoxaprop was applied had higher crabgrass coverage ratings than the fenoxaprop alone treatment, demonstrating that antagonism occurred. Also, there was no antagonism when the BWH was applied after fenoxaprop.

1993. Data collected 26 July and 9 Aug. revealed that crabgrass coverage ratings were higher in plots treated with the tank-mix combination of fenoxaprop plus BWH and the $\mathrm{BWH}$ applied 7, 10, and 14 days before fenoxaprop (Table 2). Some crabgrass plants were injured badly by fenoxaprop on 26 July, but they were not dead.

Data collected 20 Aug. confirmed that fenoxaprop was antagonized by the $\mathrm{BWH}$ applied 7, 10, and 14 days before fenoxaprop or when the BWH was applied in tank-mix combination with fenoxaprop (Table 2). Plots treated with BWH 21 days before fenoxaprop was sprayed had crabgrass coverage ratings equivalent to plots treated with fenoxaprop alone. Plots treated with BWH 3, 5, 7, or 10 days after fenoxaprop also had crabgrass coverage ratings similar to those observed in plots treated with fenoxaprop alone. Hence, no antagonism was evident in plots treated with $\mathrm{BWH}$ at any time after fenoxaprop had been applied.

Data obtained in both years showed that smooth crabgrass control by fenoxaprop was reduced significantly when the BWH was applied $\leq 14$ days before fenoxaprop was applied. Antagonism also occurred when fenoxaprop was tank-mixed with the BWH. There was no reduction in the crabgrass control level when the BWH was applied 21 days before fenoxaprop or when the BWH was applied at least 3 days after fenoxaprop.

The ability of [ \pm ]-2-[4-(2,4-diclorophenoxy) phenoxy] propanoic acid (diclofop) to control wild oat (Avena fatua L.) is reduced by [(4chloro-2-methylphenoxy)acetic acid] (MCPA) (Olson and Nalewaja, 1982). These authors reported that MCPA prevents effective diclofop translocation in wild oat, thereby reducing herbicide effectiveness. Diclofop and fenoxaprop are members of the aryl-oxy phenoxy family; therefore, BWH applied to smooth crabgrass 14 days or less before fenoxaprop also conceivably prevents the efficient translocation of this graminicide.

\section{Literature Cited}

Dernoeden, P.H. 1986. Postemergence control of crabgrass with tridiphane and fenoxaprop. Proc. Northeastern Weed Sci. Soc. 40:287-288. (Abstr.)

Harrison, S. 1987. Antagonism of fenoxaprop by broadleaf herbicides. Proc. Northeastern Weed Sci. Soc. 41:242. (Abstr.)

Olson, W. and J.D. Nalewaja. 1982. Effect of MCPA on ${ }^{14} \mathrm{C}$-diclofop uptake and translocation. Weed Sci. 30:59-63.

SAS Institute. 1985. SAS user's guide. 5th ed. SAS Institute, Cary, N.C.

Sawyer, C.D. and J.A. Jagschitz. 1988. Crabgrass control with fenoxaprop in various tank mixtures. Proc. Northeastern Weed Sci. Soc. 42:155156. (Abstr.)

Watschke, T.L. and G. Hamilton. 1986. Crabgrass control in 1986. Proc. Northeastern Weed Sci. Soc. 40:278-279. (Abstr.) 